\title{
Implementasi Metode Simple Additive Weighting (SAW) Pada Sistem Pendukung Keputusan Pemilihan Dosen Berprestasi
}

\author{
1)Denni M Rajagukguk \\ STMIK Budi Darma Medan, JL. Sisingamangaraja No. 338 Simp Limun Medan \\ http://www.stmik-budidarma.ac.id // Email : rajdenni@yahoo.co.id \\ ${ }^{2)}$ Riswan Limbong \\ STMIK Budi Darma Medan, JL. Sisingamangaraja No. 338 Simp Limun Medan \\ http://www.stmik-budidarma.ac.id // Email : risone.budidarma@gmail.com
}

\begin{abstract}
Outstanding lecturers are lecturers who in the last three years have had very useful and proud achievements in universities of origin, and are recognized on a national or international scale. The problem in choosing an outstanding lecturer at STMIK Budi Darma was that the management did not clearly understand the terms and procedures for the requirements to participate in the selection of outstanding lecturers at the Kopertis level and even at the national level, even though there were many lecturers who wanted to follow in STMIK Budi Darma. In the absence of a system to handle, almost all lecturers cannot and do not understand what must be done in implementing the higher education tridharma that supports the selection of Lecturers with Achievement. So that the outstanding lecturer selection service was built using computer tools in the form of applications by applying the Simple Additive Weighting (SAW) method as one of the Decision Support System (DSS) methods. The output of this study is a system application for supporting lecturer selection decisions, and will produce scientific papers in the form of publication journals in non-accredited national journals, so that university leaders and lecturers can process data and obtain fast, accurate and accurate information.
\end{abstract}

\section{Kata Kunci: Sistem Pendukung Keputusan, Simple Additive Weighting, SAW, Dosen, Berprestasi}

\section{PENDAHULUAN}

Dosen adalah pendidik profesional dan ilmuwan dengan tugas utama mentransformasikan, mengembangkan, dan menyebarluaskan ilmu pengetahuan, teknologi, dan seni melalui pendidikan, penelitian, dan pengabdian kepada masyarakat. (Undang-undang nomor 14 tahun 2005, pasal 1 ayat 2).

Dosen berprestasi adalah dosen yang dalam tiga tahun terakhir memiliki prestasi yang sangat bermanfaat dan dapat dibanggakan Perguruan Tinggi asal ${ }^{[2]}$, serta diakui pada skala Nasional atau Internasional, dosen yang memiliki prestasi yang dibanggakan oleh Perguruan Tingginya dalam bidang tridarma Perguruan Tinggi seharusnya mendapat penghargaan dari pemerintah yang akan mendorong dosen tersebut untuk berprestasi secara lebih produktif. Dengan demikian prestasi yang semakin produktif itu diharapkan dapat mendorong tercapainya tujuan pengembangan sistem pendidikan tinggi khususnya, dan pembangunan Nasional pada umumnya.
Tujuan pemilihan dosen berprestasi adalah memberi pengakuan kepada dosen yang secara nyata dan luar biasa melakukan kegiatan tridarma perguruan tinggi yang hasilnya dapat dibanggakan dan sangat bermanfaat bagi kemajuan peningkatan kualitas akademik dan kelembagaan ${ }^{[3]}$. Pemilihan dosen berprestasi diharapkan bermanfaat dalam : 1. Meningkatkan motivasi secara berkelanjutan di kalangan sivitas akademika untuk "bekerja lebih keras dan lebih cerdas" dalam melaksanakan tridarma Perguruan Tinggi dan meningkatkan produktivitas Perguruan Tinggi; 2. Menciptakan suasana akademik yang mengarah kepada terwujudnya kepribadian ilmuwan yang terpuji, semangat pengabdian dan dedikasi di bidang pendidikan tinggi; 3 . Menumbuhkan kebanggaan di kalangan dosen terhadap profesinya.

Kewajiban dosen Dalam melaksanakan tugas keprofesionalan, dosen berkewajiban : melaksanakan pendidikan, penelitian, dan pengabdian kepada masyarakat; merencanakan, melaksanakan proses pembelajaran, serta menilai dan mengevaluasi hasil pembelajaran; 
meningkatkan dan mengembangkan kualifikasi akademik dan kompetensi secara berkelanjutan sejalan dengan perkembangan ilmu pengetahuan, teknologi, dan seni; bertindak objektif dan tidak diskriminatif atas dasar pertimbangan jenis kelamin, agama, suku, ras, kondisi fisik tertentu, atau latar belakang sosioekonomi peserta didik dalam pembelajaran; menjunjung tinggi peraturan perundang-undangan, hukum, dan kode etik, serta nilai-nilai agama dan etika; dan memelihara dan memupuk persatuan dan kesatuan bangsa. (Undang-undang nomor 14 tahun 2005, pasal 60)

Masalah dalam memilih dosen berprestasi jumlah dosen pada STMIK Budi Darma adalah pihak manajemen tidak begitu jelas memahami syarat dan prosedur untuk persyaratan mengikuti seleksi dosen berprestasi untuk tingkat kopertis bahkan tingkat nasional, padahal di STMIK Budi Darma banyak dosen yang mau mengikutinya. Dengan tidak adanya sebuah sistem untuk menangani maka hampir seluruh dosen tidak dapat dan tidak mengerti apa yang harus dilakukan dalam melaksanakan tridharma perguruan tinggi yang mendukung untuk ikut seleksi Dosen Berprestasi. Dari uraian diatas memberikan gambaran bahwa sistem yang ada sekarang ini tidak memberikan layanan yang optimal terhadap manajemen perguruan tinggi bagi dosen dan staff pengajar. Sehingga sudah seharusnyalah layanan informasi seleksi dosen berprestasi tersebut dibangun menggunakan tools komputer dalam bentuk aplikasi.

Dari uraian perumusan masalah di atas, agar tidak menyimpang dari tujuan yang diharapkan maka dibuat beberapa pembatasan penelitian antara lain

1. Data dosen yang digunakan adalah data 3 tahun terakhir atau sejak tahun 2014.

2. Tools yang digunakan untuk perancangan sistem ini adalah dengan bahasa pemograman PHP dan Database MySql dengan Xampp.

Sesuai dengan rumusan masalah yang telah diuraikan pada bab pendahuluan maka tujuan dari penelitian ini adalah :

1. Memberi pengakuan kepada dosen yang secara nyata dan luar biasa melakukan kegiatan tridarma perguruan tinggi yang hasilnya dapat dibanggakan dan sangat bermanfaat bagi kemajuan peningkatan kualitas akademik dan kelembagaan

2. Merancang dan membangun sebuah sistem komputer yang berbentuk aplikasi yang dapat menentukan serta memilih dosen berprestasi yang memenuhi kriteria dalam melaksanakan

Pendidikan, Penelitian, Pengabdian dan

Penunjang yang menerapkan sebuah Metode dalam mata kuliah Sistem Pendukung Keputusan.

\section{LANDASAN TEORI}

\subsection{Persyaratan dan Proses Pemilihan}

Dosen yang berminat untuk mengikuti pemilihan dosen berprestasi harus memenuhi syarat dan ketentuan yang berlaku seperti sebagai berikut ${ }^{[6]}$ :

\section{A. Persyaratan}

1. Dosen tetap Perguruan Tinggi, yang bekerja penuh waktu yang berstatus sebagai dosen tetap dan memiliki NIDN pada satuan pendidikan tinggi dan diusulkan secara tertulis oleh Pimpinan Perguruan Tinggi Negeri/Koordinator Kopertis bagi Perguruan Tinggi Swasta, dilampiri Surat Keputusan Rektor/Ketua/Direktur/ Koordinator Kopertis tentang Dosen Berprestasi;

2. Dosen yang memiliki kualifikasi akademik sekurang-kurangnya magister atau setara tanpa dibatasi usia, kepangkatan dan golongan, jabatan pimpinan Perguruan Tinggi, dan jabatan fungsional akademik;

3. Dosen yang pernah menjadi Pemenang Pertama pada tingkat Perguruan Tinggi / Kopertis dalam periode 3 (tiga) tahun sebelumnya tidak dapat diusulkan kembali.

4. Dosen yang memiliki Karya Prestasi Unggul dalam bidang :
a. Pendidikan dan Pembelajaran
b. Penelitian
c. Pengabdian pada Masyarakat

\subsection{Penilaian}

Penilaian tahap awal dilakukan terhadap semua berkas/dokumen yang masuk ke Direktorat Pendidik dan Tenaga Kependidikan, Ditjen Pendidikan Tinggi, Kementerian Pendidikan dan Kebudayaan. Pada tahap ini akan ditentukan 15 orang dosen berprestasi terbaik yang akan diundang untuk mengikuti penilaian tahap akhir.

Nilai kumulatif dosen berprestasi mencakup komponen:

a. Karya Prestasi Unggul : $75 \%$

b. Karya tridarma Perguruan Tinggi : $25 \%$

Bobot penilaian tridarma Perguruan

Tinggi dan penunjang sebagai berikut.

a. Pendidikan dan pembelajaran : $35 \%$

b. Penelitian

: $45 \%$

c. Pengabdian pada masyarakat : $10 \%$

d. Kegiatan penunjang tridarma : $10 \%$ 
Hasil penilaian tahap awal (15 finalis) akan diumumkan oleh Direktur Jenderal Pendidikan Tinggi Kementerian Pendidikan dan Kebudayaan melalui laman : www.dikti.go.id .

\subsection{Penilaian Tahap Akhir}

Penilaian tahap akhir dilakukan terhadap 15 orang yang terpilih pada tahap penilaian awal untuk menentukan tiga dosen berprestasi terbaik. Penilaian pada tahap akhir dilakukan terhadap:

a. Karya tulis ilmiah/karya seni prestasi unggul untuk penilaian tahap akhir dengan ketentuan :

1) Karya tulis ilmiah ditulis 15 - 20 halaman, di atas kertas ukuran A4 dengan spasi 1,5 dan menggunakan font 12 Times New Roman;

2) Karya tulis ilmiah berisi abstrak, pendahuluan, tujuan, landasan teori/kajian pustaka, pembahasan, kesimpulan dan daftar pustaka;

3) Karya seni dikemas dalam bentuk VCD disertai deskripsi sajian, konsep gagasan/ide, pendekatan/garap secara tertulis 15 - 20 halaman, di atas kertas ukuran A4 dengan spasi 1,5 dan menggunakan font 12 Times New Roman;

4) Karya tulis ilmiah/deskripsi karya seni ditulis dengan menggunakan bahasa Indonesia atau bahasa Inggris yang baik dan benar.

b. Penyajian karya tulis ilmiah/karya seni selama 15 menit dan dilanjutkan dengan tanya jawab selama maksimum 30 menit.

c. Pengungkapan ide atau gagasan tentang isu aktual yang akan ditentukan emudian (penilaian kepribadian).

\subsection{Sistem Pendukung Keputusan}

Pengambilan keputusan meliputi beberapa tahap dan melalui beberapa proses (Lucas, 1992). Menurut Simon (1960) ${ }^{[1]}$, pengambilan keputusan meliputi empat tahap yang saling berhubungan dan berurutan. Empat proses tersebut adalah:

\section{(1) Intelligence}

Tahap ini merupakan proses penelusuran dan pendeteksian dari lingkup problematika serta proses pengenalan masalah. Data masukan diperoleh, diproses, dan diuji dalam rangka mengidentifikasikan masalah.

(2) Design

Tahap ini merupakan proses menemukan dan mengembangkan alternatif. Tahap ini meliputi proses untuk mengerti masalah, menurunkan solusi dan menguji kelayakan solusi.

(3) Choice

Pada tahap ini dilakukan poses pemilihan di antara berbagai alternatif tindakan yang mungkin dijalankan. Tahap ini meliputi pencarian, evaluasi, dan rekomendasi solusi yang sesuai untuk model yang telah dibuat. Solusi dari model merupakan nilai spesifik untuk variabel hasil pada alternatif yang dipilih.

(4) Implementation

Tahap implementasi adalah tahap pelaksanaan dari keputusan yang telah diambil. Pada tahap ini perlu disusun serangkaian tindakan yang terencana, sehingga hasil keputusan dapat dipantau dan disesuaikan apabila diperlukan perbaikan.

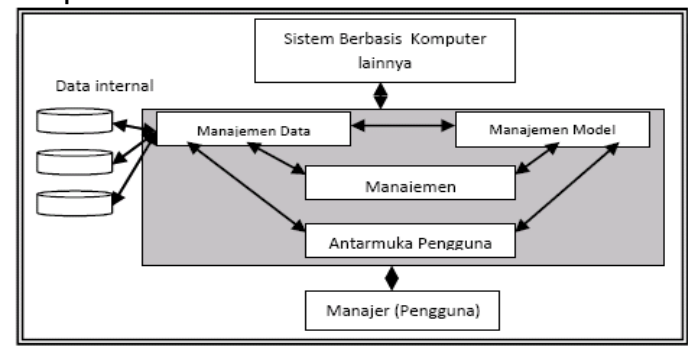

Gambar 1 Model Konseptual Sistem Pendukung Keputusan

Sumber: Decision Support Systems And Intelligent Systems (Turban, 2005)

\subsection{Simple Additive Weighting (SAW)}

Metode Simple Additive Weighting (SAW) sering juga dikenal istilah metode penjumlahan terbobot.

Konsep dasar metode SAW adalah mencari penjumlahan terbobot dari rating kinerja pada setiap alternatif pada semua atribut (Fishburn, 1967)(MacCrimmon, 1968).

Metode SAW membutuhkan proses normalisasi matriks keputusan (X) ke suatu skala yang dapat diperbandingkan dengan semua rating alternatif yang ada ${ }^{[7]}$.

Formula untuk melakukan normalisasi tersebut adalah sebagai berikut:

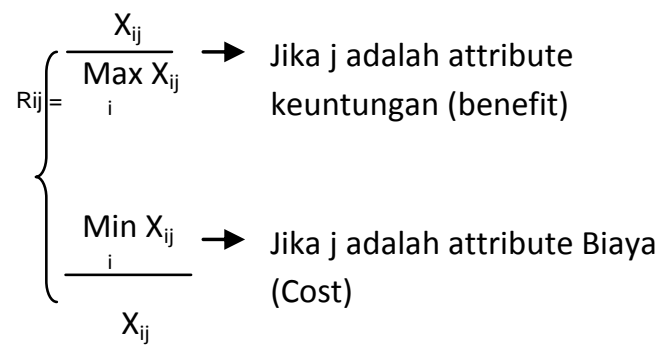

dengan rij adalah rating kinerja ternormalisasi dari alternatif Ai pada atribut $\mathrm{Cj} ; \mathrm{i}=1,2, \ldots, \mathrm{m}$ dan $j=1,2, \ldots, n$. 
Nilai preferensi untuk setiap alternatif (Vi) diberikan sebagai:

$\mathrm{V}_{\mathrm{i}}=\sum_{j=1}^{n} \mathrm{~W}_{\mathrm{j}} \mathrm{R}_{\mathrm{ij}}$

Nilai Vi yang lebih besar mengindikasikan bahwa alternatif Ai lebih terpilih.

W : Bobot (Kriteria)

$\mathrm{R}$ : Nilai dari setiap peserta untuk tiap kriteria

Dengan kata lain antara bobot kriteria (w) dikalikan dengan semua nilai tiap peserta ( $r$ ) untuk tiap kriteria dan dijumlahkan.

\section{METODE PENELITIAN}

\subsection{Tahapan Penelitian}

Penelitian akan dilakukan dengan mengadakan studi kepustakaan yaitu dengan cara mengumpulkan buku-buku pedoman yang berhubungan dengan dosen berprestasi, berkas tridharma perguruan tinggi dan juga berkas-berkas penunjang serta aturan dari dirjen dikti.

Tahapannya adalah : Observasi Lapangan, Analisis Kebutuhan (data dan aplikasi), Implementasi Metode Simple Additive Weighting (SAW) Pada Sistem Pendukung Keputusan Pemilihan Dosen Berprestasi, Implementasi Sistem Pendukung Keputusan Pemilihan Dosen Berprestasi Pada STMIK Budi Darma Medan, dan menganalisis berapa besar pengaruh Sistem Pendukung Keputusan Pemilihan Dosen Berprestasi Pada STMIK Budi Darma Medan.

Tahap 1 : Observasi Lapangan

Rencana kegiatan adalah melakukan pengumpulan data tentang berkas tridharma dosen dan jenis-jenis berkas yang ada saat melaksanakan pengajaran, penelitian dan pengabdian serta penunjang dan undangundang atau peraturan serta teori tentang system pendukung keputusan.

\section{Tahap 2 : Analisa Kebutuhan /Pengolahan data dan Analisisa}

Data yang diperoleh akan dianalisis sesuai dengan kebutuhan untuk pembelajaran dan simulasi, Analisis sistem meliputi mengidentifikasikan dan mengevaluasi permasalahan, kesempatan, hambatan yang terjadi dan kebutuhan yang diharapkan. Yang perlu didapatkan adalah Undang-Undang dan Juga software aplikasi yang akan dipakai untuk merancang sistem. Berdasarkan data analisis tersebut maka diketahui bentuk permasalahannya serta rancangan sistem baru yang akan dibuat atau dikembangkan.

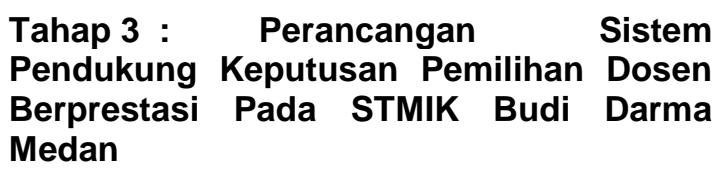

Menentukan rancangan Aplikasi Implementasi Metode Simple Additive Weighting (SAW) Pada Sistem Pendukung Keputusan Pemilihan Dosen Berprestasi Rencana kegiatan pada tahap ini adalah:

1. Perancangan Proses

Perancangan proses dilakukan dengan Diagram kontex seperti pada gambar 1 . 


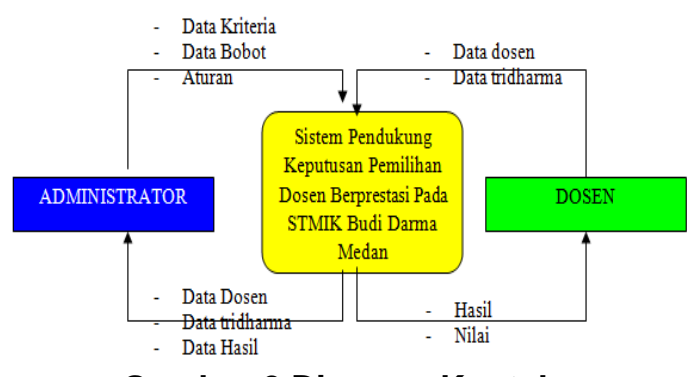

Gambar 2 Diagram Konteks

2. Perancangan Diagram Pembangunan Sistem Pendukung Keputusan

Perancangan diagram merupakan langkah prosedur penyelesaian masalah yang diekspresikan dengan simbol grafis yang baku dan lebih mudah digunakan, sehingga terhindar dari timbulnya kesalahan interpretasi bagi pengguna. Perancangan menu merupakan tahapan atau tampilan yang akan dimunculkan saat pertama kali program dijalankan dan dalam melakukan sebuah koneksi agar menghasilkan informasi yang diinginkan seperti pada gambar 2 .

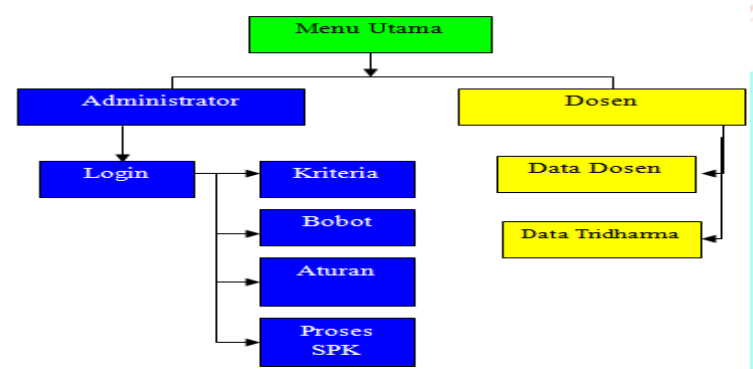

Gambar 3. Diagram Pembangunan Simulasi

3. Perancangan Antar Muka Simulasi

Perancangan antar muka tentang alur Implementasi Metode Simple Additive Weighting (SAW) Pada Sistem Pendukung Keputusan Pemilihan Dosen Berprestasi melalui komputer, dengan harapan sistem yang dibangun mudah dipergunakan (user friendly).

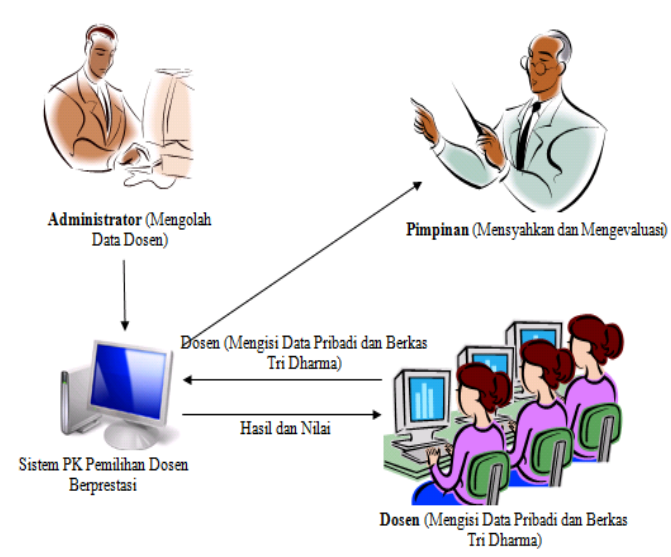

Gambar 4. Antar Muka SPK

\subsection{Bagan Alir Penelitian}

Untuk memudahkan pelaksanaan penelitian sebaiknya setiap pekerjaan disusun secara bertahap dalam bentuk diagram seperti berikut ini :

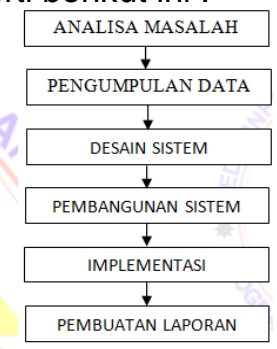

\section{Gambar 5. Bagan Alir Penelitian}

\section{ANALISA DAN PEMBAHASAN}

Penerapan sistem pendukung keputusan menggunakan metode SAW dalam pemilihan dosen berprestasi terdapat bebrapa proses yaitu sebagai berikut.

1. Menentukan Kriteria

Metode SAW membutuhkan proses normalisasi matriks keputusan $(X)$ ke suatu skala yang dapat diperbandingkan dengan semua alternatif yang ada. Dalam metode penelitian ini ada bobot dan kriteria yang dibutuhkan dalam pemilihan dosen berprestasi. Kriteria yang telah ditentukan adalah sebagai berikut:

Tabel 1. Kriteria Pemilihan Dosen Berprestasi

\begin{tabular}{|l|l|l|l|l|}
\hline NO & KRITERIA & ID & BOBOT (\%) & ATRIBUT \\
\hline 1 & Karya Prestasi Unggul & C1 & 75 & \\
\hline 2 & Pengajaran & & 8,75 & \\
\hline & a. ljazah Terakhir & C2 & 1,75 & Benefit \\
\hline & b. Mengajar & C3 & 1,75 & Benefit \\
\hline & c. Membimbing Skripsi/KP/TA & C4 & 1,75 & Benefit \\
\hline & d. Membina Organisasi/Instruktur Pelatihan & C5 & 1,75 & Benefit \\
\hline & e. Orasi IImiah & C6 & 1,75 & Benefit \\
\hline 3 & Penelitian & & 11,25 & \\
\hline & a. Penelitian Intenasional & C7 & 6 & Benefit \\
\hline & b. Penelitian Nasional & C8 & 3 & Benefit \\
\hline
\end{tabular}




\begin{tabular}{|l|l|}
\hline & c. Jurnal dan Prosiding \\
\hline 4 & Pengabdian \\
\hline 5 & Penunjang \\
\hline & a. Jabatan Fungsional \\
\hline & b. Pejabat di Kampus \\
\hline & c. Pejabat dalan Organisasi Masyarakat \\
\hline & d. Aktif dalam kepanitiaan \\
\hline & \multicolumn{2}{|c}{ Jumlah } \\
\hline & \multicolumn{2}{|}{} \\
\end{tabular}

2. Menentukan Himpunan Kriteria

Setiap kriteria memiliki himpunan dan nilai himpunan yang berbeda. Adapun himpunan dari masing masing kriteri adalah sebagai berikut.

Tabel 2. Tabel Himpunan Karya Prestasi Unggul (C1)

\begin{tabular}{|c|c|c|}
\hline NO & HIMPUNAN & NILAI \\
\hline 1 & ADA & 10 \\
\hline 2 & TIDAK ADA & 5 \\
\hline
\end{tabular}

Tabel 3. Himpunan kriteria ljazah Terakhir (C2)

\begin{tabular}{|c|c|c|}
\hline NO & HIMPUNAN & NILAI \\
\hline 1 & S3 & 10 \\
\hline 2 & S2 & 5 \\
\hline
\end{tabular}

Tabel 4 Himpunan Mengajar (C3)

\begin{tabular}{|c|c|c|}
\hline No & HIMPUNAN & NILAI \\
\hline 1 & Sangat Baik & 10 \\
\hline 2 & Baik & 8 \\
\hline 3 & Cukup & 6 \\
\hline 4 & Kurang & 4 \\
\hline 5 & Sangat Kurang & 2 \\
\hline
\end{tabular}

Tabel 5. Himpunan Membimbing Skripsi/ Kerja Praktek dan Tugas Akhir (C4)

\begin{tabular}{|c|c|c|}
\hline No & HIMPUNAN & NILAI \\
\hline 1 & Sangat Baik & 10 \\
\hline 2 & Baik & 8 \\
\hline 3 & Cukup & 6 \\
\hline 4 & Kurang & 4 \\
\hline 5 & Sangat Kurang & 2 \\
\hline
\end{tabular}

Tabel 6. Himpunan Membina Organisasi (C5)

\begin{tabular}{|c|c|c|}
\hline No & HIMPUNAN & NILAI \\
\hline 1 & Sangat Baik & 10 \\
\hline 2 & Baik & 8 \\
\hline 3 & Cukup & 6 \\
\hline 4 & Kurang & 4 \\
\hline 5 & Sangat Kurang & 2 \\
\hline
\end{tabular}

Tabel 7. Himpunan Orasi Ilmiah (C6)

\begin{tabular}{|c|c|c|}
\hline No & HIMPUNAN & NILAI \\
\hline 1 & Sangat Baik & 10 \\
\hline 2 & Baik & 8 \\
\hline 3 & Cukup & 6 \\
\hline 4 & Kurang & 4 \\
\hline 5 & Sangat Kurang & 2 \\
\hline
\end{tabular}

Tabel 8. Himpunan Penelitian Internasional(C7)

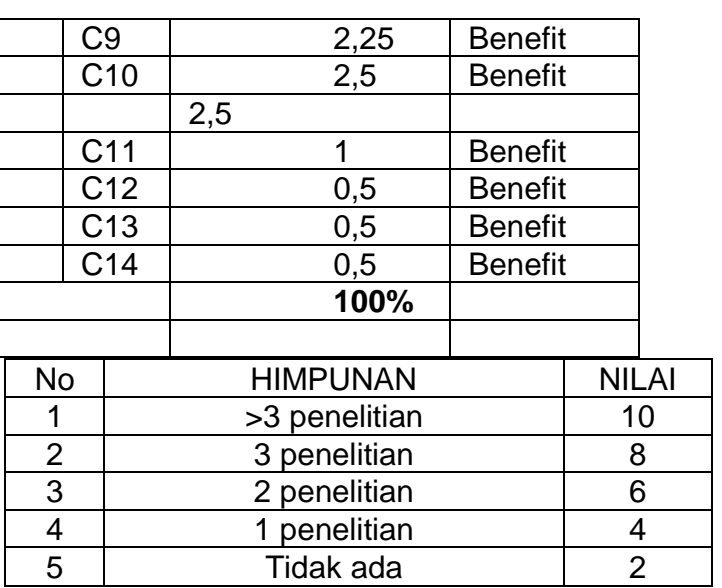

Tabel 9. Himpunan Penelitian Nasional(C8)

\begin{tabular}{|c|c|c|}
\hline No & HIMPUNAN & NILAI \\
\hline 1 & $>3$ penelitian & 10 \\
\hline 2 & 3 penelitian & 8 \\
\hline 3 & 2 penelitian & 6 \\
\hline 4 & 1 penelitian & 4 \\
\hline 5 & Tidak ada & 2 \\
\hline
\end{tabular}

Tabel 10. Himpunan Jurnal dan Prosiding(C9)

\begin{tabular}{|c|c|c|}
\hline No & HIMPUNAN & NILAI \\
\hline 1 & $>3$ penelitian & 10 \\
\hline 2 & 3 penelitian & 8 \\
\hline 3 & 2 penelitian & 6 \\
\hline 4 & 1 penelitian & 4 \\
\hline 5 & Tidak ada & 2 \\
\hline
\end{tabular}

Tabel 11. Himpunan Pengabdian Masyarakat (C10)

\begin{tabular}{|c|c|c|}
\hline No & HIMPUNAN & NILAI \\
\hline 1 & Sangat Baik & 10 \\
\hline 2 & Baik & 8 \\
\hline 3 & Cukup & 6 \\
\hline 4 & Kurang & 4 \\
\hline 5 & Sangat Kurang & 2 \\
\hline
\end{tabular}

Tabel 12. Himpunan Jabatan Fungsional (C11)

\begin{tabular}{|c|c|c|}
\hline No & HIMPUNAN & NILAI \\
\hline 1 & Guru Besar / GB & 10 \\
\hline 2 & Lektor Kepala/ LK & 8 \\
\hline 3 & Lektor/ L & 6 \\
\hline 4 & Asisten Ahli/ AA & 4 \\
\hline 5 & Tidak ada/ NONE & 2 \\
\hline
\end{tabular}

Tabel 13. Himpunan Pejabat di Kampus (C12)

\begin{tabular}{|c|c|c|}
\hline NO & HIMPUNAN & NILAI \\
\hline 1 & Pejabat & 10 \\
\hline 2 & Tidak ada Jabatan & 5 \\
\hline
\end{tabular}

Tabel 14. Himpunan Pejabat di Organisasi Masyarakat (C13)

\begin{tabular}{|c|c|c|}
\hline NO & HIMPUNAN & NILAI \\
\hline 1 & Pejabat & 10 \\
\hline 2 & Tidak ada Jabatan & 5 \\
\hline
\end{tabular}


Volume 2 No. 2, Desember 2017

http://ejournal.ust.ac.id/index.php/Jurnal Means/

Tabel 15. Himpunan Kegiatan Kepanitiaan (C14)

\begin{tabular}{|c|c|c|}
\hline No & HIMPUNAN & NILAI \\
\hline 1 & Sangat Baik & 10 \\
\hline 2 & Baik & 8 \\
\hline 3 & Cukup & 6 \\
\hline 4 & Kurang & 4 \\
\hline 5 & Sangat Kurang & 2 \\
\hline
\end{tabular}

MEANS (Media Informasi Analisa dan Sistem) p-ISSN : 2548-6985, e-ISSN : 2599-3089

3. Menentukan Rating kecocokan setiap alternative pada setiap kriteria.

Data pemilihan dosen yang digunakan adalah data dosen di STMIK Budi Darma. Data penilain dosen dapat dilihat pada Lampiran Tabel 1. Dari tabel penilaian tersebut akan dibuat data rating kecocokan setiap alternatif pada setiap kriteria.

Tabel 16. Tabel Data Rating Kecocokan

\begin{tabular}{|l|l|l|l|l|l|l|l|l|l|l|l|l|l|l|}
\hline ID & C1 & C2 & C3 & C4 & C5 & C6 & C7 & C8 & C9 & C10 & C11 & C12 & C13 & C14 \\
\hline Dosen 1 & 5 & 5 & 8 & 8 & 6 & 8 & 4 & 4 & 10 & 6 & 8 & 5 & 10 & 8 \\
\hline Dosen 2 & 5 & 5 & 8 & 8 & 8 & 6 & 2 & 4 & 6 & 6 & 8 & 5 & 5 & 8 \\
\hline Dosen 3 & 5 & 5 & 10 & 8 & 8 & 6 & 2 & 4 & 6 & 8 & 4 & 5 & 10 & 8 \\
\hline Dosen 4 & 5 & 5 & 8 & 8 & 6 & 8 & 2 & 2 & 8 & 4 & 8 & 10 & 5 & 8 \\
\hline Dosen 5 & 5 & 5 & 8 & 8 & 10 & 8 & 4 & 4 & 10 & 6 & 8 & 5 & 10 & 8 \\
\hline Dosen 6 & 5 & 10 & 4 & 6 & 6 & 4 & 2 & 2 & 4 & 4 & 8 & 10 & 10 & 8 \\
\hline Dosen 7 & 5 & 5 & 10 & 8 & 10 & 8 & 2 & 4 & 6 & 6 & 8 & 5 & 5 & 8 \\
\hline Dosen 8 & 5 & 5 & 8 & 4 & 8 & 8 & 2 & 4 & 6 & 8 & 8 & 10 & 5 & 8 \\
\hline Dosen 9 & 5 & 5 & 6 & 6 & 6 & 6 & 2 & 2 & 6 & 2 & 8 & 10 & 5 & 8 \\
\hline Dosen 10 & 5 & 5 & 8 & 10 & 6 & 8 & 2 & 4 & 8 & 8 & 4 & 5 & 5 & 8 \\
\hline Dosen 11 & 5 & 5 & 6 & 8 & 8 & 8 & 2 & 2 & 6 & 8 & 8 & 5 & 5 & 8 \\
\hline Dosen 12 & 5 & 5 & 8 & 6 & 8 & 6 & 2 & 2 & 4 & 6 & 2 & 5 & 5 & 8 \\
\hline Dosen 13 & 5 & 5 & 8 & 8 & 8 & 6 & 2 & 2 & 4 & 8 & 4 & 5 & 5 & 8 \\
\hline Dosen 14 & 5 & 5 & 8 & 8 & 10 & 6 & 2 & 4 & 4 & 6 & 4 & 5 & 5 & 8 \\
\hline Dosen 15 & 5 & 5 & 8 & 8 & 8 & 6 & 2 & 2 & 4 & 6 & 4 & 10 & 10 & 8 \\
\hline
\end{tabular}

4. Melakukan Normalisasi Matriks

Normalisasi disesuaikan dengan jenis atribut (benefit atau cost) sehingga diperoleh matriks ternormalisasi R.

Tabel 17. Proses Normalisasi

\begin{tabular}{|l|l|l|l|l|l|l|l|l|l|l|l|l|l|l|}
\hline ID & C1 & C2 & C3 & C4 & C5 & C6 & C7 & C8 & C9 & C10 & C11 & C12 & C13 & C14 \\
\hline Dosen 1 & $5 / 5$ & $5 / 10$ & $8 / 10$ & $8 / 10$ & $6 / 10$ & $8 / 8$ & $4 / 4$ & $4 / 4$ & $10 / 10$ & $6 / 8$ & $8 / 8$ & $5 / 10$ & $10 / 10$ & $8 / 8$ \\
\hline Dosen 2 & $5 / 5$ & $5 / 10$ & $8 / 10$ & $8 / 10$ & $8 / 10$ & $6 / 8$ & $2 / 4$ & $4 / 4$ & $6 / 10$ & $6 / 8$ & $8 / 8$ & $5 / 10$ & $5 / 10$ & $8 / 8$ \\
\hline Dosen 3 & $5 / 5$ & $5 / 10$ & $10 / 10$ & $8 / 10$ & $8 / 10$ & $6 / 8$ & $2 / 4$ & $4 / 4$ & $6 / 10$ & $8 / 8$ & $4 / 8$ & $5 / 10$ & $10 / 10$ & $8 / 8$ \\
\hline Dosen 4 & $5 / 5$ & $5 / 10$ & $8 / 10$ & $8 / 10$ & $6 / 10$ & $8 / 8$ & $2 / 4$ & $2 / 4$ & $8 / 10$ & $4 / 8$ & $8 / 8$ & $10 / 10$ & $5 / 10$ & $8 / 8$ \\
\hline Dosen 5 & $5 / 5$ & $5 / 10$ & $8 / 10$ & $8 / 10$ & $10 / 10$ & $8 / 8$ & $4 / 4$ & $4 / 4$ & $10 / 10$ & $6 / 8$ & $8 / 8$ & $5 / 10$ & $10 / 10$ & $8 / 8$ \\
\hline Dosen 6 & $5 / 5$ & $10 / 10$ & $4 / 10$ & $6 / 10$ & $6 / 10$ & $4 / 8$ & $2 / 4$ & $2 / 4$ & $4 / 10$ & $4 / 8$ & $8 / 8$ & $10 / 10$ & $10 / 10$ & $8 / 8$ \\
\hline Dosen 7 & $5 / 5$ & $5 / 10$ & $10 / 10$ & $8 / 10$ & $10 / 10$ & $8 / 8$ & $2 / 4$ & $4 / 4$ & $6 / 10$ & $6 / 8$ & $8 / 8$ & $5 / 10$ & $5 / 10$ & $8 / 8$ \\
\hline Dosen 8 & $5 / 5$ & $5 / 10$ & $8 / 10$ & $4 / 10$ & $8 / 10$ & $8 / 8$ & $2 / 4$ & $4 / 4$ & $6 / 10$ & $8 / 8$ & $8 / 8$ & $10 / 10$ & $5 / 10$ & $8 / 8$ \\
\hline Dosen 9 & $5 / 5$ & $5 / 10$ & $6 / 10$ & $6 / 10$ & $6 / 10$ & $6 / 8$ & $2 / 4$ & $2 / 4$ & $6 / 10$ & $2 / 8$ & $8 / 8$ & $10 / 10$ & $5 / 10$ & $8 / 8$ \\
\hline Dosen 10 & $5 / 5$ & $5 / 10$ & $8 / 10$ & $10 / 10$ & $6 / 10$ & $8 / 8$ & $2 / 4$ & $4 / 4$ & $8 / 10$ & $8 / 8$ & $4 / 8$ & $5 / 10$ & $5 / 10$ & $8 / 8$ \\
\hline Dosen 11 & $5 / 5$ & $5 / 10$ & $6 / 10$ & $8 / 10$ & $8 / 10$ & $8 / 8$ & $2 / 4$ & $2 / 4$ & $6 / 10$ & $8 / 8$ & $8 / 8$ & $5 / 10$ & $5 / 10$ & $8 / 8$ \\
\hline Dosen 12 & $5 / 5$ & $5 / 10$ & $8 / 10$ & $6 / 10$ & $8 / 10$ & $6 / 8$ & $2 / 4$ & $2 / 4$ & $4 / 10$ & $6 / 8$ & $2 / 8$ & $5 / 10$ & $5 / 10$ & $8 / 8$ \\
\hline Dosen 13 & $5 / 5$ & $5 / 10$ & $8 / 10$ & $8 / 10$ & $8 / 10$ & $6 / 8$ & $2 / 4$ & $2 / 4$ & $4 / 10$ & $8 / 8$ & $4 / 8$ & $5 / 10$ & $5 / 10$ & $8 / 8$ \\
\hline Dosen 14 & $5 / 5$ & $5 / 10$ & $8 / 10$ & $8 / 10$ & $10 / 10$ & $6 / 8$ & $2 / 4$ & $4 / 4$ & $4 / 10$ & $6 / 8$ & $4 / 8$ & $5 / 10$ & $5 / 10$ & $8 / 8$ \\
\hline Dosen 15 & $5 / 5$ & $5 / 10$ & $8 / 10$ & $8 / 10$ & $8 / 10$ & $6 / 8$ & $2 / 4$ & $2 / 4$ & $4 / 10$ & $6 / 8$ & $4 / 8$ & $10 / 10$ & $10 / 10$ & $8 / 8$ \\
\hline
\end{tabular}

Tabel 18. Hasil Normalisasi 


\begin{tabular}{|l|l|l|l|l|l|l|l|l|l|l|l|l|l|l|}
\hline ID & $\mathbf{C 1}$ & $\mathbf{C 2}$ & $\mathbf{C 3}$ & $\mathbf{C 4}$ & $\mathbf{C 5}$ & $\mathbf{C 6}$ & $\mathbf{C 7}$ & $\mathbf{C 8}$ & $\mathbf{C 9}$ & $\mathbf{C 1 0}$ & $\mathbf{C 1 1}$ & $\mathbf{C 1 2}$ & $\mathbf{C 1 3}$ & $\mathbf{C 1 4}$ \\
\hline Dosen 1 & 1 & 0,5 & 0,8 & 0,8 & 0,6 & 1 & 1 & 1 & 1 & 0,75 & 1 & 0,5 & 1 & 1 \\
\hline Dosen 2 & 1 & 0,5 & 0,8 & 0,8 & 0,8 & 0,75 & 0,5 & 1 & 0,6 & 0,75 & 1 & 0,5 & 0,5 & 1 \\
\hline Dosen 3 & 1 & 0,5 & 1 & 0,8 & 0,8 & 0,75 & 0,5 & 1 & 0,6 & 1 & 0,5 & 0,5 & 1 & 1 \\
\hline Dosen 4 & 1 & 0,5 & 0,8 & 0,8 & 0,6 & 1 & 0,5 & 0,5 & 0,8 & 0,5 & 1 & 1 & 0,5 & 1 \\
\hline Dosen 5 & 1 & 0,5 & 0,8 & 0,8 & 1 & 1 & 1 & 1 & 1 & 0,75 & 1 & 0,5 & 1 & 1 \\
\hline Dosen 6 & 1 & 1 & 0,4 & 0,6 & 0,6 & 0,5 & 0,5 & 0,5 & 0,4 & 0,5 & 1 & 1 & 1 & 1 \\
\hline Dosen 7 & 1 & 0,5 & 1 & 0,8 & 1 & 1 & 0,5 & 1 & 0,6 & 0,75 & 1 & 0,5 & 0,5 & 1 \\
\hline Dosen 8 & 1 & 0,5 & 0,8 & 0,4 & 0,8 & 1 & 0,5 & 1 & 0,6 & 1 & 1 & 1 & 0,5 & 1 \\
\hline Dosen 9 & 1 & 0,5 & 0,6 & 0,6 & 0,6 & 0,75 & 0,5 & 0,5 & 0,6 & 0,25 & 1 & 1 & 0,5 & 1 \\
\hline Dosen 10 & 1 & 0,5 & 0,8 & 1 & 0,6 & 1 & 0,5 & 1 & 0,8 & 1 & 0,5 & 0,5 & 0,5 & 1 \\
\hline Dosen 11 & 1 & 0,5 & 0,6 & 0,8 & 0,8 & 1 & 0,5 & 0,5 & 0,6 & 1 & 1 & 0,5 & 0,5 & 1 \\
\hline Dosen 12 & 1 & 0,5 & 0,8 & 0,6 & 0,8 & 0,75 & 0,5 & 0,5 & 0,4 & 0,75 & 0,25 & 0,5 & 0,5 & 1 \\
\hline Dosen 13 & 1 & 0,5 & 0,8 & 0,8 & 0,8 & 0,75 & 0,5 & 0,5 & 0,4 & 1 & 0,5 & 0,5 & 0,5 & 1 \\
\hline Dosen 14 & 1 & 0,5 & 0,8 & 0,8 & 1 & 0,75 & 0,5 & 1 & 0,4 & 0,75 & 0,5 & 0,5 & 0,5 & 1 \\
\hline Dosen 15 & 1 & 0,5 & 0,8 & 0,8 & 0,8 & 0,75 & 0,5 & 0,5 & 0,4 & 0,75 & 0,5 & 1 & 1 & 1 \\
\hline
\end{tabular}

5. Mencari alternatif terbaik menggunakan persamaan 2, maka diperoleh hasilnya sebagai berikut

Tabel 19. Nilai alternatif

\begin{tabular}{|l|r|r|r|r|r|r|r|r|r|r|r|r|r|r|r|}
\hline Id & C1 & C2 & C3 & C4 & C5 & C6 & C7 & C8 & C9 & C10 & C11 & C12 & C13 & C14 & Hasil \\
\hline Dosen 1 & 1 & 0,5 & 0,8 & 0,8 & 0,6 & 1 & 1 & 1 & 1 & 0,8 & 1 & 0,5 & 1 & 1 & 96,85 \\
\hline Dosen 2 & 1 & 0,5 & 0,8 & 0,8 & 0,8 & 0,8 & 0,5 & 1 & 0,6 & 0,8 & 1 & 0,5 & 0,5 & 1 & 92,6125 \\
\hline Dosen 3 & 1 & 0,5 & 1 & 0,8 & 0,8 & 0,8 & 0,5 & 1 & 0,6 & 1 & 0,5 & 0,5 & 1 & 1 & 93,3375 \\
\hline Dosen 4 & 1 & 0,5 & 0,8 & 0,8 & 0,6 & 1 & 0,5 & 0,5 & 0,8 & 0,5 & 1 & 1 & 0,5 & 1 & 91,275 \\
\hline Dosen 5 & 1 & 0,5 & 0,8 & 0,8 & 1 & 1 & 1 & 1 & 1 & 0,8 & 1 & 0,5 & 1 & 1 & 97,55 \\
\hline Dosen 6 & 1 & 1 & 0,4 & 0,6 & 0,6 & 0,8 & 0,5 & 0,5 & 0,4 & 0,5 & 1 & 1 & 1 & 1 & 90,0125 \\
\hline Dosen 7 & 1 & 0,5 & 1 & 0,8 & 0,8 & 1 & 0,5 & 1 & 0,6 & 0,8 & 1 & 0,5 & 0,5 & 1 & 93,4 \\
\hline Dosen 8 & 1 & 0,5 & 0,8 & 0,4 & 1 & 1 & 0,5 & 1 & 0,6 & 1 & 1 & 1 & 0,5 & 1 & 93,575 \\
\hline Dosen 9 & 1 & 0,5 & 0,6 & 0,6 & 0,6 & 0,8 & 0,5 & 0,5 & 0,6 & 0,3 & 1 & 1 & 0,5 & 1 & 89,0625 \\
\hline Dosen 10 & 1 & 0,5 & 0,8 & 1 & 0,6 & 1 & 0,5 & 1 & 0,8 & 1 & 0,5 & 0,5 & 0,5 & 1 & 93,625 \\
\hline Dosen 11 & 1 & 0,5 & 0,6 & 0,8 & 0,8 & 1 & 0,5 & 0,5 & 0,6 & 1 & 1 & 0,5 & 0,5 & 1 & 91,825 \\
\hline Dosen 12 & 1 & 0,5 & 0,8 & 0,6 & 0,8 & 0,8 & 0,5 & 0,5 & 0,4 & 0,8 & 0,3 & 0,5 & 0,5 & 1 & 89,5625 \\
\hline Dosen 13 & 1 & 0,5 & 0,8 & 0,8 & 0,8 & 0,8 & 0,5 & 0,5 & 0,4 & 1 & 0,5 & 0,5 & 0,5 & 1 & 90,7875 \\
\hline Dosen 14 & 1 & 0,5 & 0,8 & 0,8 & 1 & 0,8 & 0,5 & 1 & 0,4 & 0,8 & 0,5 & 0,5 & 0,5 & 1 & 92,0125 \\
\hline Dosen 15 & 1 & 0,5 & 0,8 & 0,8 & 0,8 & 0,8 & 0,5 & 0,5 & 0,4 & 0,8 & 0,5 & 1 & 1 & 1 & 90,6625 \\
\hline
\end{tabular}

Setelah dilakukan perhitungan maka diperoleh bahwa dosen dengan ID Dosen 5 yang layak menjadi seorang dosen terbaik. Adapun nama nama dosen terbaik berdasarkan rangking adalah sebagai berikut.

Tabel 20. Hasil Perangkingan

\begin{tabular}{|c|l|l|}
\hline Rangking & \multicolumn{1}{|c|}{ Nilai } & \multicolumn{1}{|c|}{ ID } \\
\hline 1 & 97,55 & D5 \\
\hline 2 & 96,85 & D1 \\
\hline 3 & 93,625 & D10 \\
\hline 4 & 93,575 & D8 \\
\hline
\end{tabular}

\begin{tabular}{|l|l|l|}
5 & 93,4 & D7 \\
\hline 6 & 93,3375 & D3 \\
\hline 7 & 92,6125 & D2 \\
\hline 8 & 92,0125 & D14 \\
\hline 9 & 91,825 & D11 \\
\hline 10 & 91,275 & D4 \\
\hline 11 & 90,7875 & D13 \\
\hline 12 & 90,6625 & D15 \\
\hline 13 & 90,0125 & D6 \\
\hline 14 & 89,5625 & D12 \\
\hline
\end{tabular}




\begin{tabular}{l|l|l|}
15 & 89,0625 & D9 \\
\hline
\end{tabular}

\section{Implementasi}

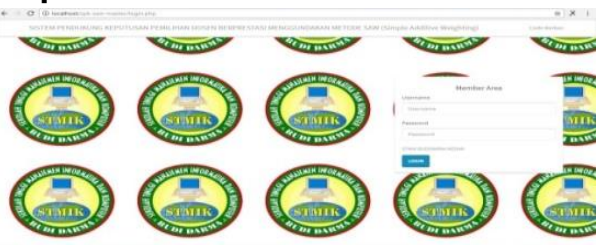

Gambar 6. Halaman Utama

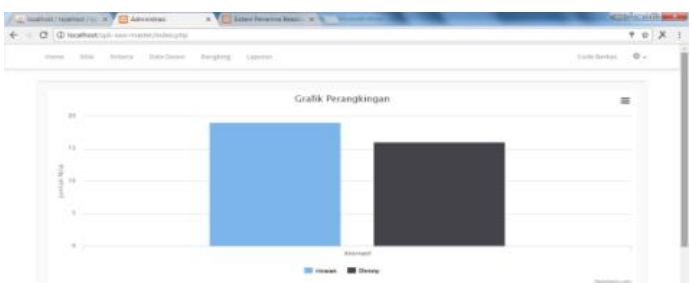

Gambar 7. Desain Halaman Nilai Prefensi

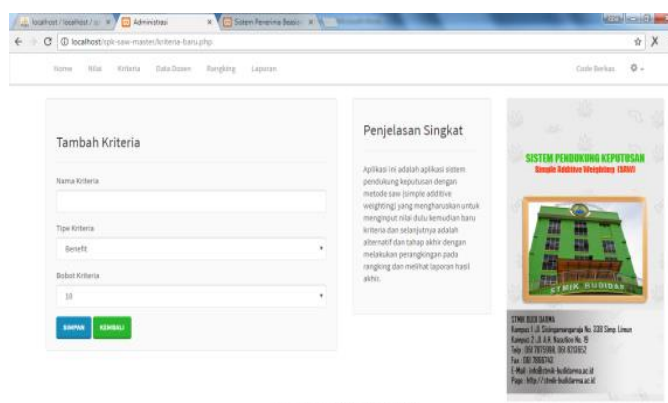

Gambar 11. Tambah Kriteria

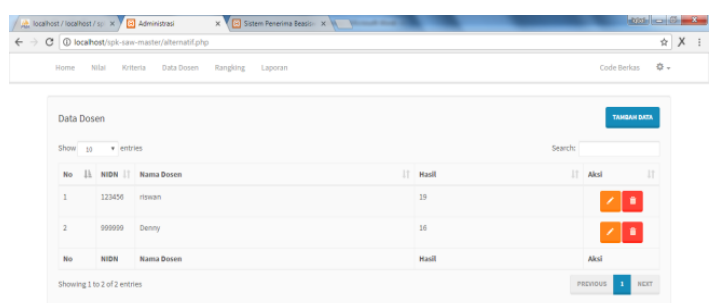

Gambar 12. Data Dosen

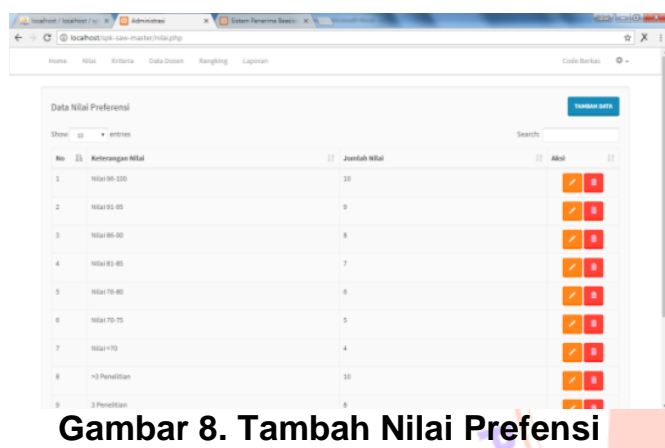

Gambar 8. Tambah Nilai Prefensi

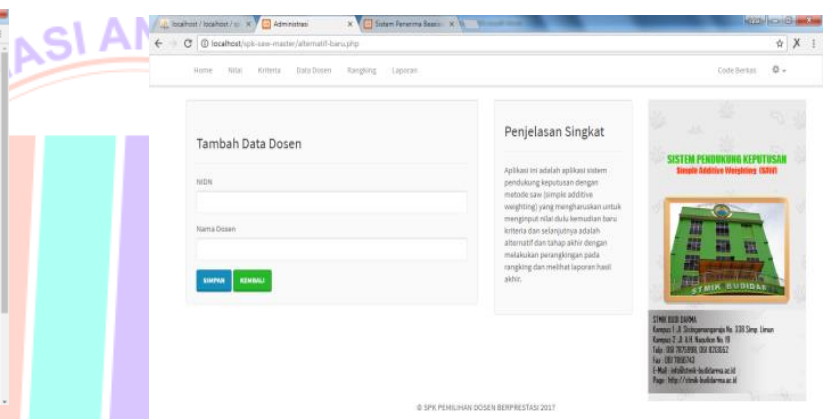

\section{Gambar 13. Tambah Data Dosen}

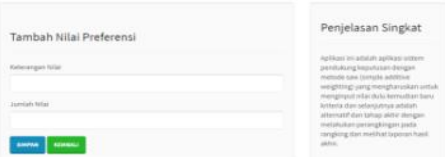

$=-$

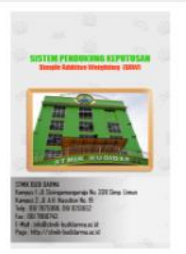

Gambar 9. Desain Halaman Kriteria

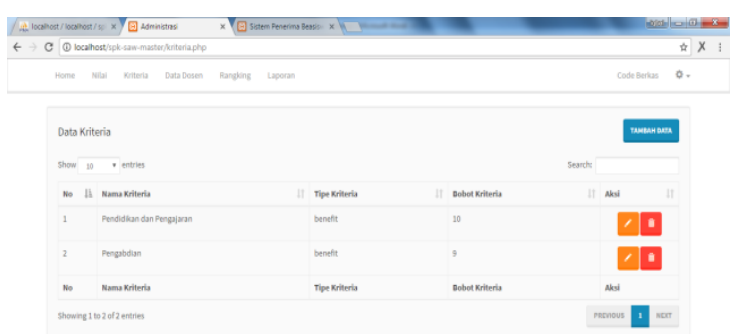

Gambar 10. Data Kriteria

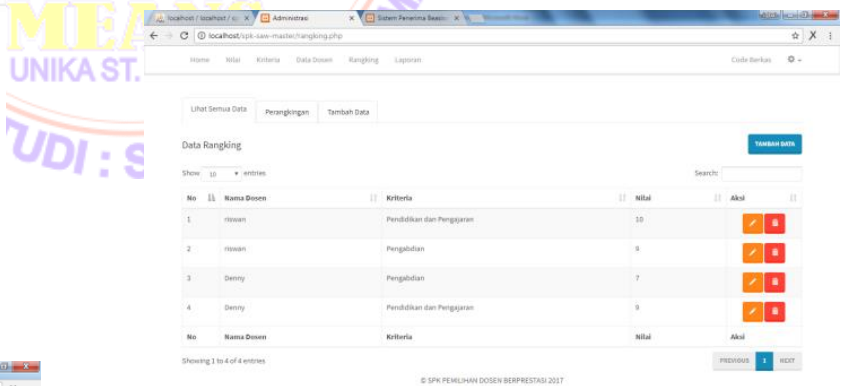

Gambar 14. Data Rangking
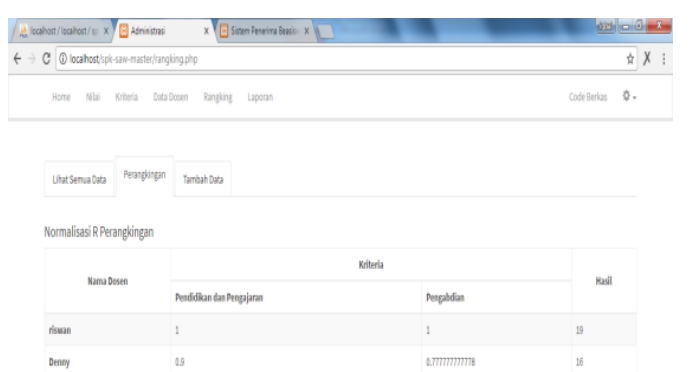

Gambar 15. Normalisasi R Perengkingan 


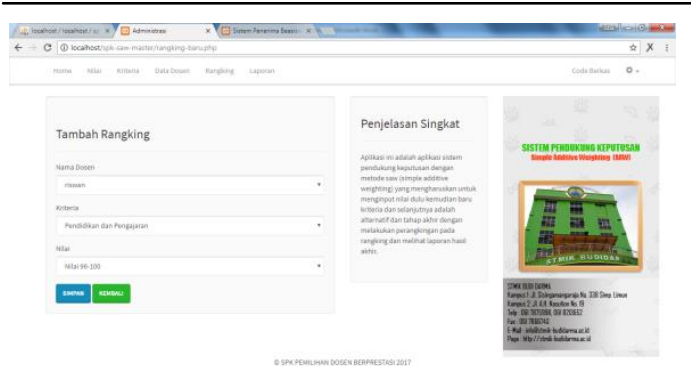

Gambar 15. Tambah Data

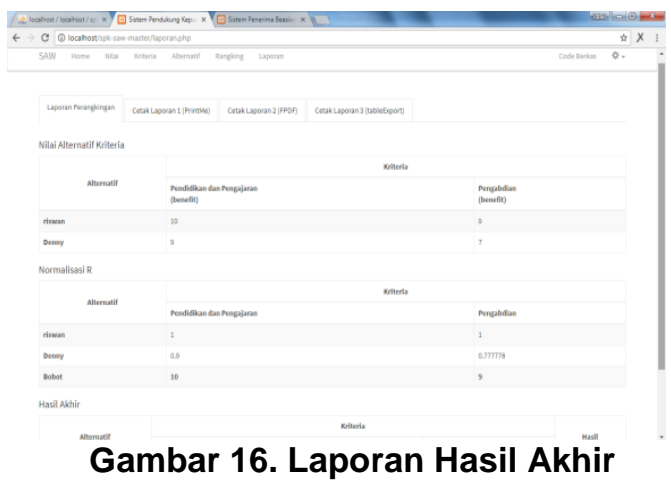

Bumiputera 1912 cabang Jakarta Timur”, Jurnal Psikologi Vol. 5 No. 1, Juni 2007, Jakarta, 2007

4. Tata, Sutabri, "Analisa Sistem Informasi", Andi, Yogyakarta, 2005.

5. Turban dkk. "Decision Support System and Intelligent System (Sistem Pendukung Keputusan dan Sistem Cerdas", Andi, Yogyakarta, 2005.

6. Pedoman Dosen Berprestasi, Kementerian Pendidikan dan Kebudayaan Direktorat Jenderal Pendidikan Tinggi Direktorat Pendidik dan Tenaga Kependidikan, Jakarta, 2014

7. Limbong, T., Implementasi Metode Simple Additive Weighting (SAW) Untuk Pemilihan Pekerjaan Bidang Informatika. SNIKOM 2013 ICT System Security, 2013.

\section{KESIMPULAN}

Berdasarkan hasil penelitian yang telah dilakukan dapat disimpulkan beberapa hal sebagai berikut :

1. Sistem pendukung keputusan pemilihan dosen berprestasi menggunakan Metode SAW telah berhasil dibangun di lingkungan STMIK Budi Darma Medan untuk membantu menyelesaikan permasalahan penentuan dosen berprestasi.

2. Metode SAW dapat diimplementasikan sebagai salah satu alternative dalam proses pengambilan keputusan.

3. Sistem ini sedapat mungkin menjalankan proses secara objektif sesuai dengan kriteria yang diberikan.

\section{UCAPAN TERIMAKASIH}

Terimakasih kepada DP2M Dikti yang telah membantu pembiayaan melalui Hibah Penelitian Dosen Pemula Tahun Anggaran 2017.

\section{DAFTAR PUSTAKA}

1. Hasan, M. Iqbal, "Pokok-Pokok Materi Teori Pengambilan Keputusan", Ghalia, Jakarta, 2004.

2. Nutriana Hidayati, "Penentuan Penilaian Dosen Teladan dengan Metode Forward dan Backpropagation", Semarang, 2013

3. Sulis Mariyanti, Renny Meinawati, "Peranan Motivasi Berprestasi Terhadap Prestasi Kerja pada Agen yang bekerja di Kantor Operasional Pondok Gede dan Kalimalang AJB 